\title{
INVESTIGATION OF BARRIERS TO INTEGRATED PADDY AND BEEF CATTLE FARMING IN ORGANIC AGRICULTURAL SYSTEM
}

\author{
Purnomo S.H., Emawati S., Sari A.I., Rahayu E.T. \\ Socio-Economic Lab, Department of Animal Science, Faculty of Agriculture, \\ University of Sebelas Maret, Surakarta, Indonesia \\ Handayanta E., Hanifa A. \\ Animal Feed and Nutrition Lab, Department of Animal Science, Faculty of Agriculture, \\ University of Sebelas Maret, Surakarta, Indonesia \\ *E-mail: sutrisnohadi@staff.uns.ac.id
}

\begin{abstract}
Integrated crop and livestock system is an alternative to increase animal and crop production simultaneously and improve land quality through efficient use of natural resources. One application of crop-livestock integration is organic agriculture. Organic agriculture provides an alternative integration of livestock and plants in realizing sustainable agriculture and zero waste. However, farmers find it is not easy to implement organic agriculture due to several barriers to the adoption of this technology both in terms of external and internal factors of farmers. The aim of this study was to investigate the barriers that occur in organic farmers in Surakarta, Central Java, Indonesia. This study selected 130 farmers as the sample for this research by using convenience sampling method. The study found that based on factor analysis the main barriers to the implementation of organic agriculture among farmers were: production, natural resources, attitude and knowledge, infrastructure, organizational and market barriers.
\end{abstract}

\section{KEY WORDS}

Barriers, paddy-cattle integration, organic agriculture, farming.

Agricultural sector mainly consists of crop and livestock in an integrated and complementary system. Crop-livestock integrated systems are an integrated system between plants and livestock that has the purpose of utilizing waste from one another. For example, livestock waste can be used as a nutrient source for plants, while agricultural waste can be used as a source of feed for livestock (Hilimere, 2011). Crop-livestock integration system is a system that practically aims to achieve adequate profits with a sustainable level of production and minimize negative impacts from environmental damage due to chemical usage. According to Gupta et al. (2012), in terms of nature conservation, crop-livestock integration produces several advantages such as increasing soil fertility, increasing crop production, recycling nutrients, improving land use and improving environmental sustainability.

Thawaf et al. (2017) confirmed that integration of Pasundan cattle and paddy farming in West Java produces the optimum family revenue per year, with ratio of $6.02 \mathrm{AU}$ and 0.5 hectare (ha) of paddy farming. Efforts to integrate livestock and rice plants according to Syamsu (2013) will produce a positive influence both socially and economically. For example, integration between cattle and rice will produce economic benefits and optimize the use of natural resources. Syamsu (2007) emphasizes that to realize this integration model, farmers' knowledge and skills are needed, at least farmers must be able to process fertilizer and apply the technology of processing rice straw as animal feed. Thus, integration of cattle and rice is expected to be one of the best ways to realize sustainable agriculture by taking into account environmental, social and economic aspects. Integrated Farming System whether plantation crops or feed crops, is a potential alternative which can solve the problem of plantation business, feed crops and even livestock problems (Rundengan et al., 2013; Boonyanuwat and Wongsri, 2016),. Munandar et al (2011) concluded that the integrated 
crop-livestock farming yielded some benefit to mitigate the impact of climatic change through supplementation of concentrate feed, bio digester installation and cattle dung composting had a role in lowering methane emissions from livestock activities.

According to CEC (2012), the implementation of livestock crop integrated systems for sustainable agriculture is organic agriculture. This system will have a contribution to food security, product diversification, and environmental conservation in the context of rural development. Organic agriculture will provide alternatives to the sustainability of conventional agricultural production (Mader et al., 2002). However, some experiences around the world regarding transition from conventional agriculture to organic agriculture must consider several barriers such as changes in management of agricultural cultivation, aspects of knowledge and acceptance of farmers (Hilimere, 2011).

Jahroh (2010) proposed three approaches to develop organic agriculture as follows: (1) development approach for self-reliance community approach, (2) income generating approach, and (3) nature conservation approach. First, subsistence/self-reliant community approach proposes the development of organic agriculture based on own production and community consumption that will create community with subsistence or self-reliance. Second, income generating approach emphasizes the development of organic agriculture based on its profitability with premium prices and niche markets. Despite a philosophy that organic agriculture lives in harmony with nature by avoiding the use of chemo-synthetic input, organic product consumers come from the middle and upper classes who are willing to pay a relatively higher price. Third, nature conservation approach emphasizes the importance of organic agriculture in preserving nature, including living things and the environment. Some organizations, mostly NGOs, with strong ideals about nature conservation have convinced both farmers to practice organic agriculture and consumers to consume organic products.

Kauffman, et al. (2011) stated that the adoption of organic agriculture is a choice that is not easy for farmers. Farmers will be faced with several barriers both from the internal and external of farmers. These barriers can be technical, economic, social, cultural (Herman et al., 2018). Koesling et al. (2008) also highlighted several issues related to the increasingly comprehensive technical and economic feasibility issues; this can overcome the main barriers for conventional farmers to turn into organic farmers. Padel et al. (2017) argued that transition from conventional agriculture to organic farming can be influenced by several factors including farmers' perceptions of the market, technical expertise, capital information, organic product certification and social barriers. Ullah et al. (2015) identified that several things, namely natural resources, market demand and government policies are some of the main things in the decision to convert from conventional systems to organic systems. Schneeberger et al. (2003) found that farmers were reluctant to adopt organic farming because of cultivation technique problems in the form of weed, disease and insect control as well as labor. In developing countries, product certification is also another challenge faced when converting into organic farmers. However, according to Reynolds (2004), some barriers and expensive certification of organic products will motivate farmers to improve the quality of organic products so as to increase the price of premiums to be marketed by large companies.

This study aimed to investigate the barriers to the adoption of organic agriculture as an implementation of paddy-cattle integration in Surakarta. By identifying these factors, it is expected to increase the knowledge and perceptions of farmers about organic farming. When these factors have been identified, then the results of this study can be used by government or other organizations to solve problems of organic agriculture and improve the adoption of this system.

\section{METHODS OF RESEARCH}

This was a survey research using a structured questionnaire instrument as a tool for data collection. The respondent was determined by using purposive sampling with criteria the farmer who has cattle and land of paddy cultivation. The respondent in this study were farmers who were members of farmer groups in Greater Solo such as in Karanganyar, 
Boyolali, Sragen and Sukoharjo with totally 130 respondents. To determine the validity of the instrument, as shown in Table 3, the factor analysis results from six factors (production, natural resources, attitude and knowledge, infrastructure, organizational and market barriers) suggested a satisfying validity test (with factors loading $>0.7$ ). Cronbach 's alpha was calculated to measure the reliability instrument and the result was 0.88 indicating that the instrument has achieved reliability point. The questionnaire included two parts: the first part consisted of 20 item questions to rank barriers to organic agriculture and the second part consisted of questions about individual characteristics. The respondents were asked about the level of importance to determine the ranking of problems using six-point Likert scale, ranging from "not important" (1) to "very important" (6).

\section{RESULTS AND DISCUSSION}

Demographic characteristics. The results of the study showed that most of the respondents were men who had an average age of 48 years. The educational levels of the respondents were Junior high school (52\%), followed by elementary school (30\%). Mostly these farmers had more than 15 years of farming experiences. In terms of income, their average income was around IDR 1,250,000 per month and most of them had medium income IDR 1,000,000 and 1,500,000. In average, they had three family members.

Ranking of barriers to organic agriculture. The result of barrier ranking is presented in Table 1. It can be seen from the Table 1 that the two most important barriers to the implementation of organic agriculture are lack of access to the right market to sell organic products and unwillingness of people to pay more for organic rice. The next barrier is farmers' lack of knowledge and education to implement organic agriculture. Other barriers in accordance with the number of ranking can be seen in Table 1.

Table 1 - Ranking of barriers to organic agriculture

\begin{tabular}{lll}
\hline Rank & Description & Mean \\
\hline 1 & There is lack of access to the right market to sell organic product & 4.76 \\
\hline 2 & People do not want to pay more for organic rice & 4.74 \\
\hline 3 & I do not know how to cultivate. & 4.28 \\
\hline 4 & I do not have enough knowledge and education about organic paddy & 4.23 \\
\hline 5 & The ownership of cattle as fertilizer producers is still limited & 3.95 \\
\hline 6 & There is lack of access to warehouse to store these products & 3.82 \\
\hline 7 & Organic paddy cultivation requires a lot of labor force & 3.73 \\
\hline 8 & There is lack of access to required input & 3.67 \\
\hline 9 & There is lack of organizations that certifies organic rice & 3.63 \\
\hline 10 & There is lack of capital access for organic paddy production & 3.64 \\
\hline 11 & There is lack of road access to land cultivation & 3.53 \\
\hline 12 & I have no interest and desire to cultivate this type of product. & 3.42 \\
\hline 13 & I do not have enough time for organic cultivation & 3.16 \\
\hline 14 & There are not enough suppliers of natural enemies of insect & 3.08 \\
\hline 15 & The government does not support organic paddy & 2.68 \\
\hline 16 & Existing natural resources are not suitable and chemicals are needed & 2.62 \\
\hline 17 & There is lack of government subsidies & 2.48 \\
\hline 18 & The climate conditions are unsuitable for organic paddy. & 2.07 \\
\hline 19 & Brokers and buyers have important role in the price determination & 2.03 \\
\hline 20 & There is lack of access to transportation & 1.98 \\
\hline
\end{tabular}

Data Accuracy Analysis. This study used Cronbach's Alpha to determine the reliability value of the instrument. Nunnaly (1978) gave a provision that Cronbach's Alpha score of 0.70 or higher shows acceptable reliability values. The reliability test results on the instrument showed that the value of Cronbach's Alpha was higher than 0.80. As shown in Table 2, the values of reliability achieved for each of the variables: 0.87 for production barriers, 0.812 for natural resources barriers, 0.804 for attitude and knowledge barriers, 0.88 for infrastructure barriers, 0.833 for organizational barriers and 0.84 for market barriers.

Based on the factor analysis using the Varimax Rotation Method, the research variables were categorized into 6 factors (Table 2). These variables were extracted into 6 
groups, including production barriers, natural and resources barriers, attitude and knowledge barriers, infrastructure barriers, organizational barriers and market barriers.

Table 2 - Number of factors extracted

\begin{tabular}{llll}
\hline Factors & Eigen values & \% of variance & \% Cumulative variance \\
\hline Market barriers & 4,573 & 16,181 & 16,141 \\
Production barriers & 2,978 & 13,251 & 29,352 \\
Natural resources barriers & 1,711 & 11,223 & 40,566 \\
Attitude and knowledge & 1,456 & 11,211 & 51,657 \\
Infrastructure barriers & 1,171 & 8,288 & 59,936 \\
Organizational barriers & 1,137 & 7,721 & 67,672 \\
\hline
\end{tabular}

As shown in Table 2, the six factors above explain about $67.67 \%$ of the total $\%$ variance. This shows that $32 \%$ of the total variance was explained by other variables not included in this study. The results of factor analysis can be seen in Table 3 .

Table 3 - Result of Factor Analysis

\begin{tabular}{|c|c|c|c|}
\hline Factors & Variable & $\begin{array}{l}\text { Loading } \\
\text { factor }\end{array}$ & $\begin{array}{l}\text { Chronbach's } \\
\text { alpha }\end{array}$ \\
\hline \multirow{3}{*}{ Market barriers } & Consumers do not want to pay more for organic rice & 0.86 & \multirow{3}{*}{0.840} \\
\hline & Middleman have important role in the price determination & 0.73 & \\
\hline & There is lack of access to the right market to sell this product. & 0.76 & \\
\hline \multirow{4}{*}{ Production barriers } & There is lack of capital access for organic paddy production & 0.82 & \multirow{4}{*}{0.87} \\
\hline & Organic cultivation requires a lot of labor force & 0.73 & \\
\hline & There is lack of access to the input required & 0.88 & \\
\hline & There are not enough suppliers of natural enemies of insect & 0.78 & \\
\hline \multirow{3}{*}{ Natural resources barriers } & The climate conditions are unsuitable for organic paddy & 0.85 & \multirow{3}{*}{0.812} \\
\hline & $\begin{array}{l}\text { The existing natural resources are not sufficient and } \\
\text { chemicals are mandatory }\end{array}$ & 0.76 & \\
\hline & The ownership of cattle as fertilizer producers is still limited & 0.78 & \\
\hline \multirow{4}{*}{$\begin{array}{l}\text { Attitude and knowledge } \\
\text { barriers }\end{array}$} & I have no interest to cultivate this type of products. & 0.78 & \multirow{4}{*}{0.804} \\
\hline & $\begin{array}{l}\text { I do not have enough skill and knowledge to perform organic } \\
\text { agriculture }\end{array}$ & 0.83 & \\
\hline & I do not know organic cultivation technique & 0.79 & \\
\hline & I do not have enough time for organic cultivation & 0.82 & \\
\hline \multirow{3}{*}{ Infrastructure barriers } & There is lack of access to transportation & 0.86 & \multirow{3}{*}{0.880} \\
\hline & There is lack of road access to land cultivation & & \\
\hline & there is lack of access to warehouse to store these products & 0.87 & \\
\hline \multirow{3}{*}{ Organizational barriers } & There is lack of organizations that certify organic products. & 0.86 & \multirow{3}{*}{0.833} \\
\hline & $\begin{array}{l}\text { There is lack of support from government to organic } \\
\text { agriculture }\end{array}$ & 0.72 & \\
\hline & There is lack of government subsidies & 0.71 & \\
\hline
\end{tabular}

Jahroh (2010) stated that the implementation of organic agriculture as a new technology will face some barriers. According to Darnhofer et al. (2005), these barriers can be in the form of market, organizational, cultural, social and technical barriers. Therefore, this study aimed to identify some barriers and investigate their impacts on the adoption of organic agriculture. The results regarding barrier ranking suggested that access to organic rice market is one of the major barriers because without access to the market it is not possible to cultivate. The result also showed that there are still many people who do not want to pay more for organic rice, unless the organic products have organic certification from institutions officially appointed by the government.

The results of the factor analysis indicated that the barriers in implementing organic farming can be categorized into 6 factors consisting of production, natural resources, attitude and knowledge of farmers, infrastructure, organizations and market barriers. These six factors can explain $67.67 \%$ of all the barriers (Table 2 ). From the perspective of farmers, the major barrier is market barrier. This shows that farmers feel they do not have market access to sell organic products. This is consistent with the opinion of Darnhofer et al (2005) that consumers do not want to pay more for organic products than non-organic products. As a result, farmers are reluctant to convert from conventional cultivation to organic cultivation. The second barriers are production barriers, as one important factor for the adoption of organic agriculture in term of input access such as labor, natural capital such as cattle 
ownership (Syamsu et al., 2013) and the unavailability of organic enemies of insect that should be used in organic agriculture methods. Schneeberger et al. (2002) added that technical barriers and unavailability of production inputs such as seeds, organic insecticides and labor can create constraints on the application of organic agriculture.

The third factor, natural resources barriers such as limited ownership of cattle, unsuitability of climate conditions, insufficient natural resources making chemicals use mandatory, are also a part of the major barriers that prevent farmers from converting to organic agriculture. The fourth factor is attitude and knowledge barriers. According to the perspective of farmers, they do not have the interest to switch to organic farming because they lack of knowledge and technical skills needed to carry out organic cultivation. In addition, there is lack of awareness of the benefits to be gained from applying organic farming such as land and environmental conservation as well as food security. The fifth factor is infrastructure barriers. Lack of transportation to transport fertilizer to the land and to transport agricultural products to warehouses are the barriers to be considered. In addition, road access to organic farming land is also an important barrier. Another barrier felt by farmers is lack of government support in the application of organic farming. The government must improve the certification of organic products, so that farmers can more easily obtain certification for their products as official organic products. The government must also provide support for organic farmers in terms of subsidies and soft loans for the application of organic cultivation. Thus, these will increase farmers' awareness to switch from conventional agriculture to organic farming.

\section{CONCLUSION}

Based on the above discussion, there are some conclusions that can be drawn so that organic farming can be realized. First, the market for organic products should be developed through supply chain management which has marketing channels from producers to end users. Second, some inputs needed by farmers must be available and easily obtained. Third, the government must provide motivation to farmers to switch to organic farming with organizational support such as establishing an organization that certifies organic products and provides financial assistance such as loans and subsidies to farmers. In addition, farmers need assistance and guidance in the application of organic farming so as to increase their confidence that organic farming will bring benefits.

\section{ACKNOWLEDGMENTS}

The authors would like to acknowledge the research grant from the Ministry of Research Technology and Higher Education of the Republic of Indonesia, through the National Strategic Research Program, 2018.

\section{REFERENCES}

1. Boonyanuwat, K. and M. Wongsri. 2016. Integrating Thai Native Cattle into Organic Paddy Rice Farming System in Bokcharearn Community, Ubonratchathani Province. Rajabhat Agric. 15 (1) : 22-26.

2. CEC (Commissions of the European Communities). 2002. Analysis of the possibility of a European action plan for organic food and farming. Commission staff Working Paper, Brussels: Commissions of the European Communities.

3. Darnhofer I, Schneeberger W, Freyer B. 2005. Converting or not converting to organic agriculture in Austria: Farmer types and their rationale. Agric. Hum. Values, 22: 39-52

4. Gupta V, P.K. Rai and K.S. Risam. 2012. Integrated Crop-Livestock Farming Systems: A Strategy for Resource Conservation and Environmental Sustainability. Indian Research Journal of Extension Education, Special Issue (Volume II), 2012 
5. Herman A, M. Lähdesmäki and M. Siltaoja. 2018. Placing resilience in context: Investigating the changing experiences of Finnish organic farmers, Journal of Rural Studies, 58: 112-122.

6. Hilimire, K. 2011. 'Integrated Crop/Livestock Agriculture in the United States: A Review', Journal of Sustainable Agriculture, 35: 4, 376 - 393

7. Jahroh, S. 2010. Organic agriculture Development In Indonesia: Lessons Learned From Organic agriculture In West Java And North Sumatra. Emilie Coudel, Hubert Devautour, Christophe-Toussaint SOULARD, Bernard HUBERT. ISDA 2010, Jun 2010, Montpellier, France. Cirad-Inra-SupAgro, 11 p., 2010.

8. Mader P, Fliebach A, DuBois D, Gunst L, Fried P, Niggli U. 2002. Soil fertility and biodiversity in organic agriculture. Science 296 (5573): 1694-1697.

9. Kaufmann P, R. Zemeckis, V. Skulskis, E. Kairyte and S. Stagl, 2011. The Diffusion of Organic Farming in Lithuania, Journal of Sustainable Agriculture, 35(5): 522-549.

10. Koesling M., O. Flaten and G. Lien. 2008. Factors influencing the conversion to organic farming in Norway, International Journal of Agricultural Resources, Governance and Ecology, 7(1/2): 78-95.

11. Munandar, F. Gustiar, Yakup, R. Hayati, \& A. I. Munawar. 2015. Crop-Cattle Integrated Farming System: An Alternative of Climatic Change Mitigation. Journal of Animal Science and Technology. 38(2): 95-103

12. Nunnaly, J.C. 1978, Psychometric Theory, 2nd ed., McGraw Hill, New York.

13. Padel S, M. Vaarst and K. Zaralis, 2017. Chapter 7 Supporting Innovation in Organic Agriculture: A European Perspective Using Experience from the SOLID Project, Sustainable Development of Organic Agriculture. 2017: (115-134).

14. Raynolds L.T. 2004. The globalization of the organic agro-food networks. World Development, 32(5): 725-743.

15. Rundengan1 M.L., Z. Fanani, I. Subagiyo, F.H. Elly. 2013. Integrated Farming System Model in South Minahasa Regency - North Sulawesi. IOSR Journal of Agriculture and Veterinary Science (IOSR-JAVS). 5(6): 01-07.

16. Schneeberger W, Darnhofer I, Eder M. 2002. Barriers to adoption of organic agriculture by cash-crop producers in Austria. Am. J. Alternative. Agric, 17: 24-31.

17. Syamsu, J.A., H.M. Ali, M. Ridwan, and M.A. Asja. 2013. Analysis of Sustainability Status of Integration of Beef Cattle and Paddy with Technology Innovation of Rice Straw as Feed and Beef Cattle Manure as Fertilizer and Biogas. Environment and Natural Resources Journal. 11(2): 1-16

18. Thawaf R, M. Paturochman, L. Herlina, M. Sulistyati and A. Fitriani. 2017. The optimation of farmer families' revenue the integration of Pasundan cattle and paddy farming in West Java J. Indonesian Trop. Anim. Agric. 42(4): 270-278.

19. Ullah A, S.N.M. Shah, A. Ali, R. Naz, A. Mahar and A. Kalhoro, 2015. Factors Affecting the Adoption of Organic Farming in Peshawar-Pakistan, Agricultural Sciences, 06: 587593. 